\title{
O PRÍNCIPE ATRASADO, DE CASSIA LESLIE E RICARDO DALAI: DESCONSTRUÇÃO DAS FIGURAS DO PRÍNCIPE E DA PRINCESA NO TEATRO INFANTIL E JUVENIL
}

\author{
O PRÍNCIPE ATRASADO [THE LATE PRINCE], BY CASSIA LESLIE AND \\ RICARDO DALAI: DECONSTRUCTION OF THE PRINCE AND PRINCESS \\ FIGURES IN THEATER FOR CHILDREN AND ADOLESCENTS
}

\begin{abstract}
Marina Stuchi* Ricardo Augusto de Lima**

Resumo: Partindo do pressuposto que todo texto é um mosaico de outros textos, como queria Julia Kristeva, pretendemos discutir aqui as questões do feminino e das masculinidades no teatro escrito para crianças e pré-adolescentes, tomando como objeto de análise o recente texto dramático $O$ príncipe atrasado, de Cassia Leslie e Ricardo Dalai (2018). Como informa o subtítulo do texto, trata-se de uma paródia teatral de contos de fadas que desconstrói, com humor, estereótipos presentes nas narrativas clássicas infantis. O diferencial da obra, entretanto, é discutir tais questões a partir da perspectiva do príncipe, e não da princesa, como comumente vemos. Desta forma, o texto de Leslie e Dalai projeta, ao evidenciar a construção de uma nova figura feminina, a necessária desconstrução da figura masculina do príncipe, não acostumado a lidar com as novas princesas. Tal desconstrução promove, por sua vez, um movimento que se mostra circular e paradoxal depois de iniciado: a desconstrução do masculino exige a criação de um novo modelo, ou melhor dizendo, a reconstrução de um sujeito a partir das ruínas do sujeito antigo, pois, como toda jornada, o herói aqui também busca restabelecer o equilíbrio.

Palavras-chave: Paródia. Dramaturgia infantil e juvenil. Estereótipos de gênero. O príncipe atrasado.

Abstract: Departing from the notion endorsed by Julia Kristeva assessing every text as a mosaic of other texts, throughout this work, it is intended to discuss the matters of feminism and the masculinities in theater written for children and pre-teens. The recent dramatic text The Late Prince by Cassia Leslie and Ricardo Dalai (2018) was the object chosen for the analysis. As per its title, the piece is a theatrical parody of fairy tales were, through humor, stereotypes inhabiting classic children's narratives are deconstructed. However, the uniqueness of the work dwells in discussing the matters by the prince's perspective rather than the princess' one, as most commonly seen. Thus, Leslie and Dalai's text exposes the construction of a new female figure and promotes the necessary deconstruction of the masculine figure of the prince, who is not used to dealing with the new princesses. On its own terms, such deconstruction promotes a movement that presents itself round and paradoxical once initiated; the deconstruction of the male requires the creation of a new role model. In better words, the reconstruction of the self from the ruins of the old self is needed, once the hero seeks to reestablish the balance here, as in every journey.
\end{abstract}

Keywords: Parody. Dramaturgy for children and adolescentes. Gender stereotypes. The late prince.

\section{Introdução}

As discussões que tocamos neste texto nasceram ou se fortaleceram a partir da década de 1950, e são três os eixos que as dividem: tanto as discussões que giram em torno das questões de gênero como aquelas referente à intertextualidade inerente da criação poética ou ao teatro infantil encontraram a partir desse período um terreno fértil

\footnotetext{
*Doutoranda em Letras, Estudos Literários, pela Universidade Estadual de Londrina. Bolsista CAPES. E-mail: marinastuchi@gmail.com.

** Doutor em Letras pela Universidade Estadual de Londrina. Pós-doutorando no Programa de pósgraduação em Letras da Universidade Estadual de Londrina, bolsista PNPD-CAPES. E-mail: ricardodalai@gmail.com.
} 
para sua frutificação, promovendo um debate que permanece vigoroso (e necessário) até os dias de hoje.

A respeito do caráter intertextual da literatura, encontramos já em Julia Kristeva, mãe do termo, o entendimento de que todo texto é um mosaico de outros textos, entendimento que questiona e desconstrói as esferas de produção e recepção literárias tal como eram entendidas. $\mathrm{O}$ autor vive, como afirmou Harold Bloom, uma angústia da influência na qual a busca pela superação a partir do confronto se torna motriz de toda criação poética e, grosso modo, ficcional ou literária.

Longa manta de retalhos que cobre, enquanto camada, o que chamamos de Cultura, a Literatura foi, a partir da década de 1960, influenciada por questões e perspectivas que valorizavam novas formas de pensar a constituição cultural humana influenciadas pelas lutas feminina, negra e homossexual, por exemplo. O estudos do pós-colonialismo, ou os chamados Estudos Culturais, são cruciais para pensarmos a desconstrução que aqui gostaríamos de evidenciar em $O$ príncipe atrasado: uma paródia teatral de contos de fadas, de Cassia Leslie e Ricardo Dalai (2018).

Não é figura de linguagem afirmar que o teatro existe desde quando existe isto que chamamos de Humanidade. Seja enquanto linguagem artística, seja enquanto instinto vital, podemos inclusive dizer que foi graças ao instinto mimético que nos tornamos isto que somos: humanos, criadores e acreditadores de ficções, estabelecedores de laços, de crenças comuns. Como afirma Margot Berthold em sua História Mundial do Teatro (2014, p. 1):

O teatro é tão velho quanto a humanidade. Existem formas primitivas desde os primórdios do homem. A transformação numa outra pessoa é uma das formas arquetípicas da expressão humana. O raio de ação do teatro, portanto, inclui a pantomima de caça dos povos da idade do gelo e as categorias dramáticas diferenciadas dos tempos modernos.

E citando o historiador do teatro Oskar Eberle (1954), Berthold (2014, p. 2) lembra que o teatro primitivo é arte incorporada na forma humana, ampliando e abrangendo todas as possibilidades do corpo, sendo por isso desnecessário qualquer instrumento, qualquer materialidade da linguagem a não ser aquela promovida pelo corpo, tão-somente o corpo e sua mímica, seu gesto, sua expressão. Por isso: arte imortal, porque não sabemos dizer se seríamos possível sem ela. Graças a ela somos.

Sob uma perspectiva similar, Sigmund Freud (2014) se referiu à infância como época na qual a ficção comanda o imaginário - ficção entendida aqui como elaboração consciente da imaginação a partir do real ou crença inconsciente em algum ser ou realidade fantasiosa ou onírica, já que, segundo Freud, o sonho seria o primeiro movimento ficcional do sujeito, movimento totalmente involuntário e dramatizado que se converte, quando percebido e compreendido, em ferramenta para o brincar, ação que por sua vez obedece a um movimento voluntário do sujeito que institui inclusive regras, embora seja uma ação igualmente dramatizada e ficcional. Assim como o sonho, o brincar, para Freud, é um dos elementos que torna possível apreender o real. Esse brincar, essa imaginação nascida do sonho, individual ou coletivamente criada, é um mundo dramático, teatro na sua forma mais primitiva.

No início, Freud já diz, não haverá limites entre o real e o imaginário; esses vão pouco a pouco se fortalecendo e estabelecendo critérios racionais na apreensão do mundo e nas relações humanas. O brincar e o sonho se tornam cada vez mais distantes do sujeito, que mergulha gradativamente no oceano sério e triste da maturidade onde sonho é ilusão e brincar, infantil. Cada vez mais séria e mais cética, a criança vai se tornando adulto. 
Como o brincar e o sonho, o teatro sempre rejeitou a totalidade da verdade ao mesmo tempo em que rejeita a totalidade da ficção. Assim, no espaço crepuscular da ficção e no espaço híbrido do teatro, o brincar e o sonho se encontram na busca por uma verdade, busca própria da Filosofia, o que nos remete à lembrança de que o teatro ocidental nasce no mesmo berço e talvez na mesma estação que o pensamento filosófico. Talvez irmãos gêmeos. Podemos pensar, inclusive, que o teatro nasce co mo uma resposta, de caráter estético e experimental, a uma questão filosófica que tenta apreender o Real insuportável da condição humana e, ao mesmo tempo, colocar o sujeito em contato com o Outro por meio de uma alteridade catártica.

Teatro é, portanto, a união dessa ação humana primitiva, o gesto mimético do brincar e do aprender, a uma linguagem artística, originando um objeto estético a partir das primeiras atividades interpretativas e comunicativas de nossa expressão: a linguagem, o mytho, e a mímesis. Entretanto, o teatro mantém um forte traço daquele caráter pedagógico do gesto mimético inicial, no primitivo da humanidade; daquele caráter de aprendizado, de imitação, de tradição, de cultura, traço percebido na própria repetição das coisas, dia após dia, das estrelas, elas se duplicando noite após noite, triplicando, todas as noites; perceber como o bicho bebe água, como o bicho caça, como o bicho se protege da chuva e do Sol, e fazer igual. Repetir o gesto do bicho. Tudo na vida é repetição: o Sol, as estações, as constelações, os rituais, as pessoas, o mesmo andar inicial e o mesmo dormir no fim da clareira, na última caverna. $\mathrm{O}$ fim. $\mathrm{O}$ trágico.

Tendo isso em mente, quase inútil relembrar aqui o caráter pedagógico e lúdico do gênero dramático em sala de aula. Como o teatro, a educação se constrói e reflete que a existência humana se realiza através da dialética homem-mundo, como já escreveu Merleau-Ponty (1972, apud SILVA, 2005, p. 77).

Educação é o resultado dessa dialética; como tal evidencia-se como sendo um projeto através do qual o homem 'apreende' os significados que estão em circulação no interior do seu mundo histórico e cultural. Esta 'apreensão' é dialética porque o homem somente existe enquanto dialoga - no diálogo recorrente das várias épocas a verdade plena vai paulatinamente abrindo caminho através do choque de posições antagônicas [...].

Trata-se, então, de pensar a existência como um constante vir-a-ser do pensamento, que reflete na sociedade não antes de refletir e transformar já o sujeito. $\mathrm{O}$ teatro possibilita essa experiência, e de forma muito singular na criança, visto que para ela a identificação entre objeto e representação se dá de maneira talvez mais evidente. $\mathrm{O}$ personagem vivo ali possibilitaria de forma mais plena a identificação projetiva promovida pelo teatro, pois, já que ele é "um processo que permite a autocompreensão, ele assume o caráter de Conscientizador para o pequeno ser." (BARROS NETO, 1984 p. 20). Em Psicanálise do Teatro Infantil, Manoel de Lemos Barros Neto (1984) é incisivo em defender que: "É através do Símbolo Vivo que o Teatro Infantil tem o grande poder de ajudar a criança a solucionar suas dúvidas ou conflitos internos". E exemplifica:

[...] a Identificação Projetiva que uma criança realiza com o personagem violento, sádico, possessivo em cena, decorre exatamente de uma necessidade de viver com tal personagem suas fantasias de violência (fantasias inconscientes), de sadismo, e de posse exclusiva sobre objetos. E é no momento em que sentimentos como os expostos 
são interpretados em cena pelos atores que a criança os percebe em si mesma. (BARROS NETO, 1984, p. 21)

A leitura psicanalítica dos efeitos do teatro na criança remete, sabemos, à própria origem simbólica da Psicanálise: a tragédia grega. Daí a facilidade em relacionar o conceito de catarse com a identificação projetiva pela empatia, isto é, pela capacidade de se colocar no lugar do outro.

A identificação projetiva também fornece a base da forma mais primitiva de formação simbólica. Pela projeção de partes de si mesmo no objeto e pela identificação de partes do objeto como partes do eu (self), o ego forma seus primeiros e mais primitivos símbolos. (BARROS NETO, 1984, p. 23)

Trata-se, como já dizia o pai da Psicanálise, de apaziguar os desejos não gratificados por meio da arte (FREUD, 2006). Daí o prazer que nasce no espectador, prazer estético, singularmente estético, empírico, que serve diretamente às necessidades do inconsciente tanto da criança quanto do adulto. Particularmente o caso infantil, devemos ter em mente que a criança é, muito mais que o sujeito maduro, um ser em processo de desenvolvimento, sendo que a identificação projetiva auxiliaria na capacidade de ver-se por meio do outro, ver-se no outro. Como também já escreveu Freud (1996, p. 306), "A transferência é uma prova do fato de que os adultos não superaram sua antiga dependência infantil [...]. Dessa forma, o tratamento analítico atua como uma segunda educação do adulto, como um corretivo da sua educação enquanto criança."

São essas reflexões que direcionam nosso olhar, quase de forma clichê, ao conto de fadas, pois esses registros escritos do imaginário humano já se mostraram terreno fértil para essa leitura da criança sob o viés psicanalítico ${ }^{1}$. Para exemplificar essas relações, tomaremos o texto dramático $O$ príncipe atrasado, que se apresenta como uma paródia de contos de fadas na forma teatral, o que, por sua vez, une todas as questões que levantamos até o momento.

Como já foi dito, tomaremos como ponto de partida a definição de Kristeva (1974, p. 440-441) ao discutir o conceito de intertextualidade: "tout texte se construit comme mosaïque de citations, tout texte est absorption et transformation d'un autre texte". Sabe-se que Kristeva parte das elaborações teóricas de Bakhtin em torno do caráter dialógico do romance, criando um sistema no qual a obra se torna pensável em relação a outras, modificando o então estatuto de criação. Como escreveu Bakhtin (2006, p. 191), o "texto só ganha vida em contato com outro texto (em contexto). Somente neste ponto de contato entre textos é que uma luz brilha, iluminando tanto o posterior como o anterior, juntando dado texto a um diálogo." Esse sistema foi recuperado posteriormente por Laurent Jenny (1979, p. 5) ao afirmar que "só se apreende o sentido e a estrutura duma obra literária se a relacionarmos com os seus arquétipos - por sua vez abstraídos de longas séries de textos, de que constituem, por assim dizer, a constante.".

Inútil argumentar em defesa da intertextualidade visto que grandíssima parte da produção literária a partir do período conhecido como pós-modernismo emprega esse recurso de diversas e criativas maneiras, promovendo diferentes efeitos na leitura muitas

\footnotetext{
${ }^{1}$ Para aprofundamento na relação entre Psicanálise e contos de fadas, ver o conhecidíssimo trabalho de Bruno Bettelheim, A Psicanálise dos Contos de Fadas. São Paulo: Paz e Terra, 1978.
} 
vezes - senão sempre - de forma crítica e metalinguística. Os estudos literários e teatrais encontraram aí solo fértil para uma pesquisa que continua a pleno vapor, ampliando o universo de conceitos intertextuais e práticas e recursos de criação.

Estamos pensando, grosso modo, a intertextualidade como toda e qualquer relação, explícita ou implícita, que um texto (aqui pensando o literário, de qualquer gênero, oral ou escrito), mantém com outros textos, anterior ou concomitantemente produzidos. Os diferentes níveis dessa relação estabelecem, por sua vez, diferentes categorias intertextuais, como a alusão, a citação, a releitura, a paródia etc. Nesse resgate de textos, a metatextualidade se revela, visto que a literatura está pensando e escrevendo a si mesma. Como lembra Bakhtin, nenhuma palavra é nossa, ou está sendo dita pela primeira vez, adônica. Todas trazem em si a influência de outras vozes. "O texto", escreveu Barthes (2004, p. 64), "é feito de escrituras múltiplas, oriundas de várias culturas e que entram umas com as outras em diálogo, em paródia, em contestação [...]”. Ao reconhecer o texto fonte e a forma como ele é trabalhado na nova ficção, ativa-se a memória discursiva do leitor ou, se preferir, a sua memória literária (cf. SAMOYAULT, 2008). Claro que essa memória literária que Samoyault defende não é, apenas, a memória particular do leitor e seu acervo; mas, principalmente, afirmar que a literatura "se escreve com a lembrança daquilo que é, daquilo que foi." (SAMOYAULT, 2008, p. 47). E tanto o viés discursivo quanto o literário afirmam a necessidade do leitor reconhecer o intertexto.

[...] Afinal, compreender um signo consiste em aproximar o signo apreendido de outros signos já conhecidos; em outros termos, a compreensão é uma resposta a um signo por meio de signos. E essa cadeia de criatividade e de compreensão ideológicas, deslocando-se de signo em signo para um novo signo, é única e contínua: de um elo de natureza semiótica (e, portanto, também de natureza material) passamos sem interrupção para um outro elo de natureza estritamente idêntica. (BAKHTIN, 2006, p. 32)

Essa percepção, dirá Bakhtin em outro texto, projeta uma compreensão completa o texto que se exerce de maneira ativa e criadora, pois "prossegue o ato criador, aumenta as riquezas artísticas da humanidade. Cocriatividade do compreendente" (BAKHTIN, 2003, p. 382). Também relacionando intertextualidade e a tessitura do texto/espetáculo teatral, Carlos Augusto Nazareth (2012, p. 26) entende o texto como expressão do universo, composto por milhões de microtextos.

E mais ainda: textos de arte refletiram, por mimetismo, conforme o conceito aristotélico, os textos da vida. É a vida representada na arte. Portanto, o texto teatral seria um dos muitos possíveis, e, como os outros, reproduziram o mundo real por meio da mimesis.

Inerentes à literatura e ao processo de criação, recursos intertextuais ganham novos moldes com o passar do tempo, pois, "se a escrita é sempre uma reescrita, mecanismos sutis de regulação, variáveis segundo as épocas, trabalham para que ela não seja simplesmente uma cópia, mas uma tradução, uma citação" (COMPAGNON, 2007, p. 42). Logo, a constituição de uma obra literária, ou, pleonasticamente, de uma obra literária intertextual, dá-se também pelo choque entre uma tradição literária e cultural e um aqui-agora da criação e da recepção, que se dá pela exigência do hoje de valores estabelecidos no ontem. Novamente, e talvez soaremos repetitivos, o cenário maravilhoso dos contos de fadas é privilegiado, uma vez que, como se sabe, o gênero se 
consolida como dispositivo burguês na educação de seus filhos e como objeto burguês na formação de sua classe e economia. Os valores depositados nos contos de fadas, como mostrou Bettelheim (1978), ecoam ainda hoje na nossa constituição ocidental de sujeitos, estabelecendo juízos, preceitos, códigos de conduta, moral e ética, enfim: uma série de conceitos que foram, um dia, tomados como sólidos e insolúveis, mas que hoje se mostram frágeis para a expressão e existência de nossas sociedade e cultura.

Ao olhar para a representação das mulheres na arte, nesse caso nos contos de fadas e na dramaturgia, é necessário procurar novos significados, colocar novas questões e, principalmente, estarmos munidos de novas ferramentas de leitura que nos auxiliem a escavar nas entrelinhas o jogo de poder presente na literatura e no discurso. Devemos, antes de tudo, nos indagar sobre o que queremos saber e como podemos encontrar respostas às perguntas que ainda ecoam num vazio crítico e teórico. Para Showalter (1994, p.28-29) não é possível para a crítica feminista encontrar um passado útil na tradição da crítica androcêntrica.

Ela - a mulher, a leitora, a crítica - tem mais a aprender a partir dos estudos da mulher do que dos estudos literários e culturais da tradição anglo-americana, mais a aprender a partir da teoria feminista internacional do que de outro seminário sobre os mestres. Deve encontrar seu próprio assunto, seu próprio sistema, sua própria teoria, e sua própria voz; pois foi a partir de assuntos, sistemas, teorias e vozes masculinas que ela foi, até então, formada discursivamente em textos literários ou não.

Desde o surgimento da literatura no mundo ocidental, as mulheres foram retratadas como seres inferiores e que não possuíam direito a expressar suas opiniões. Um bom exemplo pode ser encontrado já na Odisseia, de Homero, na qual temos registrado um homem mandando uma mulher ficar calada. Telêmaco, em duas situações distintas, manda Penélope se calar, pois do discurso e das armas os homens cuidarão. Assim ordena:

Mas entra na casa e cuida de teus próprios afazeres, do tear e da roca, e ordena às criadas que executem o trabalho; o discurso ocupará os varões todos, mormente a mim, de quem é o poder na casa.

(HOMERO, 2018, I, v. 356-359)

O texto é repetido por Telêmaco no Canto 21, v. 350-353, alterando apenas a palavra discurso por arco. Esse famoso 'cala a boca', ou a-mulher-não-tem-direito-ater-opinião, já tem quase três mil anos e é apenas um dos inúmeros exemplos dados no livro Mulheres e poder: um manifesto, de Mary Beard. Situação semelhante é encontrada séculos depois, no teatro de Aristófanes, por exemplo, quando Lisístrata argumenta:

LISÍSTRATA - [...] Muitas vezes ouvíamos vocês [os homens] discutindo, decidindo a vida e a morte do povo, a sorte e a felicidade dos nossos cidadãos. $\mathrm{E}$ os argumentos nos pareciam vistos pelo avesso e de cabeça pra baixo. Arriscávamos então uma pergunta temerosa. Com o coração pesado, mas mantendo um sorriso, indagávamos: "Querido, na Assembleia, hoje, você falou alguma coisa pela paz?" "Pra quê?", a resposta vinha como um trovão, pois vocês sabem tudo. "Que é que você tem com isso? Isso é da sua conta? Onde é que se viu mulher se imiscuir em interesses públicos? Cala a boca!" E adivinha o que fazíamos nós? (Comissário faz gesto de quem não sabe.) Calávamos a boca.

CLEONICE - Eu não calava, não. Falava sempre tudo que me vinha. 
COMISSÁRIO - E o teu marido, não te dava as bofetadas que você pedia?

LISÍSTRATA - Pois eu não dizia mais nada. Só noutra oportunidade, diante de uma decisão ainda mais grave e mais estúpida, eu não me continha: "Mas meu marido, como é que você participou de semelhante cegueira, que pode até ser fatal, pelo menos vai ser um desastre?" Ele apenas me olhava com infinito desprezo e respondia: "Volta pro teu bordado, cuida do teu lençol ou terá muito de que se arrepender. Guerra é pra homem". (ARISTÓFANES, 2003, p. 26)

Ou, ainda:

LISÍSTRATA - [...] Chegou a nossa vez de apontar o caminho. COMISSÁRIO - Vocês apontarem o caminho? Mas é uma audácia que ultrapassa todas as audácias que já existiram.

LISÍSTRATA - Quieto aí! Quieto e calado!

COMISSÁRIO - O quê? Acredita mesmo que eu vá obedecer ordens de um ser inferior, desonrando minhas roupas de homem? Antes mil mortes.

LISÍSTRATA - Se são só roupas que você teme desonrar, não se incomode. Troca comigo. Eu prometo que manterei a dignidade delas. (Alto.) Mas cala! (ARISTÓFANES, 2003, p. 27)

Ainda no campo dramático, Sófocles e Eurípides fizeram eco à misoginia, mesmo quando incluíam figuras femininas como heroínas. Tanto em Antígona como em Medeia temos personagens-título fortes, mas que são colocadas sob a ótica da irresponsabilidade e da loucura, da desobediência e da malícia, visões que ecoam até a literatura atual, passando pelas mulheres inconstantes de Shakespeare e pelas astutas do Realismo. Como lamenta Ismene à sua irmã Antígona nos versos 68 a 73 da tragédia sofocliana:

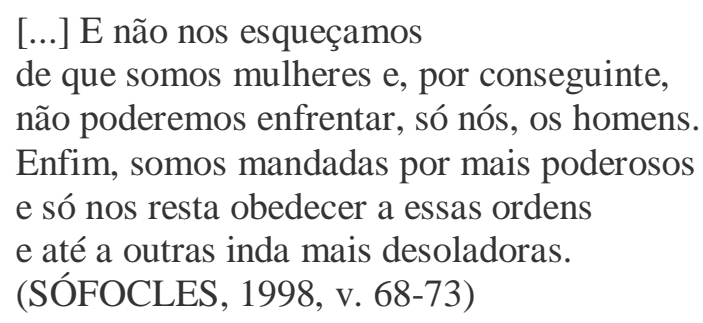

$\mathrm{Ou}$, ainda, o belo e triste lamento de Medeia às mulheres:

Entre os seres com psique e pensamento, quem supera a mulher na triste vida?

Impõe-se-lhe a custosa aquisição

do esposo, proprietário desde então

de seu corpo - eis o opróbio que mais dói!

(EURÍPEDES, 2010, v. 230-234)

Esses trechos nos dão pistas de como as vozes femininas foram silenciadas no âmbito público (e literário) na Grécia de antigamente, tradição intensificada no pensamento romano. De fato, trata-se de uma postura que se repete ao longo de toda a literatura das Idades Antiga e Média, a qual dá ênfase à autoridade da voz masculina em detrimento à voz feminina. Essa ideia, a do silenciamento das mulheres, nos leva a uma questão ainda muito pertinente no mundo contemporâneo: ao olhar para a história do 
mundo ocidental, para isso que chamamos de tradição, existe uma separação radical (real, cultural, simbólica, discursiva e imaginária) entre as mulheres e o poder. Logo, se as mulheres foram silenciadas, qual a representação que temos delas na literatura, visto que tal literatura foi produzida, ou ao menos mediada e publicada, quase que exclusivamente por homens até o século XX? É importante pensarmos quais foram e continuam sendo os mecanismos que silenciam as mulheres, que impõem padrões de beleza e de postura a elas, que não as levam a sério e que as afastam dos centros do discurso e do poder.

Para pensarmos exemplos mais próximos, que servem de evidência da influência desses estereótipos na cultura ocidental, basta olharmos para a representação das princesas de animações dos estúdios Disney, muitas delas extraídas dos contos de fadas. No longa de animação A pequena sereia, para conquistar o príncipe, a princesa Ariel faz um acordo, um pacto com a bruxa do mar, Úrsula, que lhe pernas e pede, em troca, sua voz. É um exemplo que, muitas vezes, assim como as ideologias "camufladas" nos contos de fadas, nos passa despercebido. Nesse caso, a mulher que deseja casar-se deve, antes de mais nada, ser silenciada, pois é a voz do marido que deve sobressair no relacionamento, mas tudo bem: como canta a canção cantada por Úrsula a Ariel, a sereiazinha terá ainda sua aparência, seu belo resto, a linguagem do corpo.

Em O príncipe atrasado, Cassia Leslie e Ricardo Dalai (2018) retomam alguns contos de fadas e quadros/imagens pertencentes ao imaginário maravilhoso para questionar, por meio de um texto paródico, valores e códigos morais de forma lúdica e bem-humorada, intentando, aparentemente, aproximar o espectador infantil da representação. Como escreve Sonia Pascolati $(2018$, p. 8) na apresentação do texto,

O princípio criador da peça é a intertextualidade, com duplo propósito: seduzir o leitor/espectador pelo jogo da identificação de personagens dos contos de fadas tradicionais e possibilitar a revisão de padrões de comportamento solidificados por essa mesma tradição de castelos, reis e princesas. A literatura é uma manifestação cultural sempre afinada com o contexto histórico, e as produções intertextuais conseguem colocar em diálogo diferentes contextos históricos, sociais, econômicos e ideológicos.

$\mathrm{O}$ adjetivo atrasado do título revela-se, já nas primeiras cenas, ambíguo: trata-se tanto de um atraso no tempo diegético, isto é, no agir da ação, quanto um atraso na forma do pensar, já que ele, príncipe típico de contos de fadas tradicionais, depara-se com princesas cujo pensamento é mais "contemporâneo", por assim dizer, pensamentos e formulações pós-revolução feminista. O cenário, os personagens, os nomes: tudo nos remete ao imaginário maravilhoso clássico, mas o choque entre esse imaginário e essas personagens femininas provocam, de imediato, dois efeitos: o estranhamento devido à quebra do horizonte de expectativas do espectador/leitor e o humor que resulta dessas situações. As ilustrações de Roberta Asse reiteram essa mescla de tempos ao apresentar imagens que misturam fotografias e traços manuais, que formam uma outra coisa, um outro tempo já não construído em passado e presente, mas suspendido no nível atemporal da realidade ficcional.

$\mathrm{O}$ que queremos dizer é que o texto exige o choque com os textos anteriores, como que para promover, justamente, a dialética que permitirá o nascimento de uma nova forma de pensar. Como defendia Mikhail Bakhtin (2003), nenhum texto pode ter um sentido isolado de outros, pois sua semântica é resultado da relação com os elementos que o cercam: outros textos, os contextos histórico e social, o sujeito que o lê, 
o sujeito que o escreve etc. Logo, o sentido do texto está na relação dialógica estabelecida entre texto, autor e leitor. Assim, ao utilizar um intertexto, conforme entendia Compagnon (2007), esvazia-se o sentido primeiro, dando-lhe autonomia para existir no texto posterior, fazendo com que o intertexto exista como metáfora, isto é, algo que diz algo sem dizê-lo, cujo signo, já sem valor, gera outro signo, ainda igualmente sem valor, e ambos têm seu valor reconhecido pela memória do leitor.

A estrutura é tradicional, formada por prólogo e três atos, divididos por entreatos, organização bem-vinda quando visamos o leitor/espectador em formação ou mesmo o pequeno ator que pode vir a representar o texto. Já no Prólogo se percebe o jogo entre tradição clássica e cultura contemporânea ao apresentar elementos em contraste: ao explicar o que nos leva àquela ação, o prólogo evoca as introduções de contos de fadas, com seus reis, fadas e bruxas, com um diálogo maior com o conto "A Bela Adormecida": um rei e uma rainha que muito ansiavam por um filho estavam, enfim, celebrando o nascimento de uma princesa. Mas, como conta a história tradicional, uma das fadas não foi convidada. E a voz in off do Prólogo muda de tom ao completar:

Por algum problema nos correios, não sei. Só sabemos que a bendita fada não foi convidada. E não é que o rei e a rainha tiveram o azar de ser a pior fada? Aquela mais chata, a mais ranzinza... (em tom de segredo) Dizem até que estava envolvida com uns negócios estranhos. Falaram também que ela dava aulas numa escola na Inglaterra e tudo mais. Tinha até um aluno preferido. Voldemort, o nome dele. Não lembro. Não deve ser alguém conhecido. (LESLIE; DALAI, 2018, p. 13)

Não só no campo da Literatura e de outras artes, mas a contemporaneidade surge nas próprias ações, dispositivos e mídias, como nesse momento, quando a fada não convidada se enche de ódio ao ver, nas redes sociais, fotografias e publicações sobre o grande evento. Sabemos que ela se encheu de ira e ódio e que avançou sobre a pequena princesa, lançando sobre ela uma maldição de eterno sono. E então temos o primeiro ato.

Atrasado, como informa o título, ao chegar para acordar a Bela Adormecida, o Príncipe já a encontra acordada há muito tempo, desperta para o mundo e para os seus afazeres como rainha. O diálogo surge, então, como ágon, jogo e retórica, teatral e comunicativo, como argumentação, persuasão, disputa, sem dúvida, já que é movimentado, de um lado, pela emoção e, do outro, pela razão, como se percebe no trecho a seguir:

PRINCESA Sim... Já que príncipe algum chegava, acordei pra vida. Meu pai, o rei, está muito cansado e minha mãe, a rainha, quer que ele se aposente. Então estou me preparando para ser a nova rainha.

PRÍNCIPE E quem será o rei?

PRINCESA Não terá um rei.

PRÍNCIPE (novamente espantadíssimo) Como não terá rei?!

PRINCESA Oras bolas!... Não tendo. Não teremos rei. Mas rei não é ESSENCIAL num reino, você deve saber.

PRÍNCIPE (mais inconformado ainda) Claro que não! Os reis são insubstituíveis!

PRINCESA (irônica) Oi?! Em que reino você vive? Algum reino medieval?

PRÍNCIPE Não tem sentido uma rainha sem rei. 
PRINCESA (calma e conciliadora de novo) Quem faz a realeza, seu Príncipe, é a coroa. Um homem com coroa é rei. Uma mulher com coroa é rainha. Quem está ao lado é mero detalhe. Olha a Elza, do Reino Gelado. Olha a Beth, da Inglaterra. [...] (LESLIE; DALAI, 2018, p. 23)

Esse é apenas um dos embates dramáticos entre o Príncipe e princesas que questionam a tradição firmada nos contos de fadas: quebram com o paradigma de donzelas indefesas, que, adormecidas, aguardam o seu salvador. Mas aqui a própria figura do Príncipe se desfaz, pois o estereótipo de corajoso, galante e forte soa quase irônico ao encontrarmos um sujeito que já não corresponde ao ideal masculino firmado na tradição dos cavaleiros medievais e do conto maravilhoso e, consequentemente, na sociedade ocidental. Esses embates entre masculino e feminino e, principalmente, entre o masculino de antes e esse masculino de agora, é que alimentam a tensão dramática, distanciada no Ato 2 com o baile oferecido pelo Príncipe para encontrar, quem sabe, sua rainha; um baile "como aquele onde Romeu conheceu Julieta" (LESLIE; DALAI, 2018, p. 25). O deslocamento do enredo de A Bela Adormecida para o de Cinderela acontece de forma natural e sem tropeços, visto que o universo da ficção é apreendido como um todo. Como já apontou Pascolati (2018 p. 9) na apresentação de $O$ príncipe atrasado:

O baile realizado no Ato 2, recurso privilegiado para reunir tantas personagens do universo maravilhoso, parece reencenar a visita que essas mesmas personagens fazem ao Sítio do Picapau Amarelo em uma das narrativas de Reinações de Narizinho, invenção do pai da literatura infantojuvenil brasileira, Monteiro Lobato, e com preocupação semelhante à de nosso escritor nacionalista, pois todos dançam uma quadrilha, bailado típico das festas brasileiras mais populares.

O baile enquanto ferramenta para que o príncipe encontre sua amada reforça a busca do personagem e daí sua potência dramática. Além disso, existe a busca própria dos personagens do conto maravilhoso, em especial na figura do príncipe, herói cuja jornada na busca por uma realização pessoal conhecemos, e descobrimos que, para isso, é necessário ele percorrer um caminho para alcançar, enfim, seu objeto de desejo. A singularidade aqui está, entretanto, nos próprios objetos de desejo, isto é, nas princesas: são elas que, aos olhos do príncipe, colocam obstáculos para sua conquista. Ao contrário, porém, dos tradicionais contos de fadas, ao receber sua recompensa, o príncipe não tem sua situação inicial transformada externamente, seja física ou socialmente $^{2}$, alterando seu "estado civil". Aqui, a transformação é exclusivamente interna, de paradigmas, de valores, de pensamentos, processo de desconstrução e reconstrução do sujeito e de sua masculinidade frente ao novo feminino.

Em verdade, as dúvidas que o príncipe tem são as dúvidas de todo sujeito diante de novos cenários sociais, culturais, políticos e mesmo econômicos; sujeitos que sofrem o choque entre a tradição, e uma série de valores e ideais que ela carrega, e as novas realidades, ou, em estreita medida, a realidade do Outro.

O convite feito ao príncipe ao ser confrontado com essas novas situações o conduz a ver o outro, ouvir o outro, experimentar como o outro a dor e o desejo, entendê-lo como um igual, um outro-eu. Essa perspectiva para se ler o cenário do conto

${ }^{2}$ Como exemplo claro dessas transformações, basta pensarmos em contos como "A bela e a fera" e, mais subjetivamente, "O patinho feio". 
maravilhoso aqui empregado parece-nos, assim, ambígua, uma vez que o próprio teatro tem, como vimos, enquanto meta, função, objetivo, a catarse, a humanização por meio do hábito ético nascido da repetição, do ensinamento, da representação, mimesis. A possibilidade de se ver no outro, de ser outro, de ver o outro e experimentar com ele durante aquele tempo que durar a ilusão. Fazer um pacto para acreditar nela enquanto durar a representação.

Parece-nos que é justamente essa 'crepuscabilidade' do enredo, essa ambientação ambígua das personae e do espaço fonte principal da exploração do humor no texto. $\mathrm{O}$ choque entre ontem e hoje não apenas desmantela os dois tempos como os mescla, como na rubrica "Príncipe na boca de cena. Um menino passa, olha-o, pega uma plaquinha no chão e escreve: \#CHATEADO. Coloca na mão do Príncipe, que mostra a plaquinha para o público." (LESLIE; DALAI, 2018, p. 25). Esse cruzamento de tempos e espaços, assim como a própria tessitura intertextual, revelam certa consciência crítica na construção dramática, percebida, também, nos próprios recursos empregados para romper com a quarta parede e aproximar espaço cênico e espectadores, pensando aqui em uma plateia idealmente infantil. Como escreve Sonia Pascolati (2018, p. 10) na apresentação já citada,

O maravilhoso é um gênero que exige a cumplicidade do receptor, a aceitação de que se está diante de um mundo cujas regras não correspondem às do cotidiano. Nesta peça, a proposta é tomá-lo apenas como ponto de partida, fazer o leitor/espectador lembrar-se do tempo em que princesas dormiam por cem anos em altas torres, à espera de um príncipe salvador, pois, logo no Prólogo, o recitante menciona a entrega de convites pelos correios e a postagem de fotos em uma rede social. Desde o início, o mundo maravilhoso é atravessado por referências contemporâneas, especialmente as tecnológicas, como internet e veículos bicombustíveis, sem falar em castelo com elevador. O ancoramento no realismo abre espaço para o questionamento da verossimilhança e a irrupção do humor, como quando o exagerado Príncipe diz ter cavalgado por mil colinas, navegado por mil riachos e viajado por mil léguas e a Camareira raciocina: "Primeiro, que isso parece mentira. Os dados não batem. Segundo: por que não pegou a linha 302, que agora passa aqui do ladinho do palácio?" (Ato 1, Cena 2).

Claro que não se pode esquecer que estamos tratando de uma estrutura fabular na qual é quase que clichê a presença de outro embate, agora a nível social, que diz respeito às duas classes apresentadas em textos dramáticos com esse tema e forma (o drama): os empregados e os patrões. Em O príncipe atrasado, temos não apenas servos, mas também camareiras, garçons e músicos, ou seja, empregados, assalariados. Todos, entretanto, são, como lembra Pascolati (2018, p. 11), herdeiros "da boa tradição dos serviçais cômicos de Molière". A ambientação não é apenas medieval e doméstica, mas também moderna e pública, mesclando também as duas esferas e criando, no choque e na mistura, humor. É o caso dos trigêmeos Teodoro, Teobaldo e Teófilo que são triplos no discurso: eles completam as frases uns dos outros. Exemplificamos:

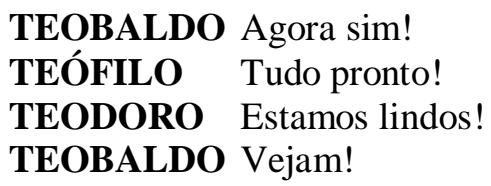




\section{TEÓFILO Os convidados... \\ TEODORO … estão chegando! (LESLIE; DALAI, 2018, p. 29)}

São eles que conduzem a quadrilha, no estilo mais brasileiro do termo, durante o baile, incorporando ao cenário do maravilhoso os populares dizeres das danças caipiras: "Olha a grande roda! [...] Olha o caracol!" [...] "Olha o túnel!" [...] "Olha o grande baile!” (LESLIE; DALAI, 2018, p. 30-31). Outras vezes, os mesmos dizeres entram em choque na trama intertextual: a resposta "É mentira!", popularmente utilizadas como recurso lúdico na dança, aqui é apresentada depois dos alardes "Cinderela, é meianoite!" e "Alguém pisou no Polegar!".

É também no baile que o Príncipe encontra suas duas próximas candidatas a princesa e rainha: Cinderela e Nzinga, que também, cada uma a seu modo, debatem com o nobre as questões relativas às novas perspectivas do ser-mulher na sociedade. Cinderela não quebra apenas com o paradigma de donzela que necessita de salvação, mas discute padrões de beleza que, sabemos, atingem e agridem principalmente as mulheres em nosso dia a dia. Como afirma Naomi Wolf (2019) em $O$ mito da beleza, os padrões de beleza foram criados e reforçados a cada forte avanço da luta feminista, desviando assim a atenção das mulheres e sugando suas energias como meio de controlar seus progressos nos campos dos direitos na sociedade.

A "beleza" é um sistema monetário semelhante ao padrão-ouro. Como qualquer sistema, ele é determinado pela política e, na era moderna no mundo ocidental, consiste no último e melhor conjunto de crenças a manter intacto o domínio masculino. Ao atribuir valor às mulheres numa hierarquia vertical, de acordo com um padrão físico imposto culturalmente, ele expressa relações de poder segundo os quais as mulheres precisam competir de forma antinatural por recursos dos quais os homens se apropriaram. (WOLF, 2019, p. 29)

Mas como toda boa Cinderela, esta também está com pressa, e não tem a paciência no debate que se revela em Nzinga, imagem da cultura e da realeza africana, tão rejeitadas na cultura ocidental. Nzinga, princesa de Ndongo, antigo reino do Congo, é a brecha aberta para desfile de outros nomes femininos da história da realeza do continente, como mostra o início do diálogo entre os dois:

PRÍNCIPE É sempre um prazer receber uma princesa tão ilustre em meu reino.

NZINGA Estamos aguardando uma visita de Sua Alteza em Ndongo. Já conhece o continente africano?

PRÍNCIPE Somente o Egito, onde reinou Cleópatra.

NZINGA Precisa conhecer os outros reinos. São maravilhosos! Ainda temos a coroa da Rainha de Sabá em nosso museu... (LESLIE; DALAI, 2018, p. 38)

É Nzinga quem se esforça e dedica maior tempo para conversar com o atrapalhado príncipe, mostrando em que pontos seus pensamentos são ultrapassados e como é necessário que ele compreenda a nova realidade, reconheça os novos valores, desconstrua sua antiga concepção de masculino e feminino e conceba uma na qual é possível abarcar as várias possibilidades de ser no mundo, e não apenas aquele que é ditada como padrão. Ao mesmo tempo em que mostra que casamento não é uma necessidade, mas apenas uma das várias possibilidades de caminhos da vida, Nzinga 
também discute o casamento por interesses e títulos, dizendo que não pode aceitar o pedido de casamento e casar para, depois, apaixonar-se. O processo é inverso. Cito-a:

NZINGA As princesas hoje buscam estudar, conhecer seus reinos, a geografia de suas terras, a história do seu povo. Algumas nem mesmo querer continuar sendo princesas. Buscam outra vida. Outras tradições. Casar não é uma prioridade para algumas. Para outras, sim. Eu quero colocar tudo em ordem no meu reino e, depois, sim, claro... Por que não? Conhecer alguém, me apaixonar... só o tempo e a vida podem dizer. [...] Amor não obedece à gente, Alteza. Amor nasce sem pedir licença. [...] (LESLIE; DALAI, 2018, p. 40)

O diálogo com Nzinga não é apenas o mais didático, mas também o mais poético. A princesa traz algo de griot, de sábia, apesar da idade. Trata-se, sem dúvida, de uma forma singular de pensar e falar, às vezes com tom profético, consolador, mas sem dúvida poético, de quem cresceu sob um céu de estrelas, como o exemplo a seguir:

\begin{abstract}
NZINGA Um dia o seu "felizes para sempre" chegará, Alteza. E você se perguntará como viveu antes de conhecer essa pessoa. Não precisará salvá-la da torre mais alta, nem a encontrá-la fazendo com que todas as moças do reino experimentem um sapatinho de cristal ou de ouro. Ela simplesmente aparecerá no seu caminho e você saberá que ali está seu verdadeiro amor. No final, vai entender que realmente a salvou, como nas histórias. Mas na vida real, Alteza, perceberá que você também foi salvo por ela. Só o amor pode dar cor a esta vida cinzenta que temos. (LESLIE; DALAI, 2018, p. 41)
\end{abstract}

Indiscutivelmente, o subjetivo poético ameniza o tom paródico e didático, afastando o texto dramático de um sistema puramente didático, embora, é claro, vinculado a ele enquanto expressão literária ou, no mínimo, exemplo de texto no gênero. Esse lirismo encontrado em certos trechos distanciam o leitor/espectador de ser um experimental passivo para também inclui-lo na experiência da linguagem, usando como meio para isso o teatro, estrutura muito eficaz, já que é, como indica Nazareth (2012, p. 26-27), ritual, linguagem e ação com sentido, "código, sintaxe; luz tem significado; movimento é narrativo; música é texto; ator em movimento é fisicalidade do teatro". Experiência muito mais que admiração, o espectador é mergulhado no próprio aqui-agora da Arte, na onipotência da ficção, tornando o teatro uma experiência singular por ser sinestésica. "Esta unidade com que os múltiplos sentidos são atingidos, de uma só vez, esse bombardeio múltiplo, que deve soar em uníssono, é que faz acontecer a experiência estética do teatro.” (NAZARETH, 2012, p. 28).

O autor também enfatiza a potência do texto dramático em sala de aula não só enquanto representação. Tomamos o texto dramático aqui não em sua potência ou realização cênica, mas enquanto linguagem, chamando de experiência não só o representar teatral, mas, antes, a experiência literária promovida pela linguagem literária.

A criança "joga" naturalmente, visualiza, vivencia, faz a leitura viva, mas, aos poucos, com o "adestramento" para uma "boa leitura" que recebe acaba perdendo esta faculdade de visualizar e construir imagens, o que permite uma compreensão integral do texto, daí a importância da leitura do texto teatral, que pode claramente exercitar essa capacidade nata de visualização por meio da imaginação, comum 
na criança pequena e que vai se perdendo ao longo de sua escolarização. (NAZARETH, 2012, p. 65)

Essa leitura, a propósito, ecoa Bachelard (1988) quando afirma que a imaginação poética nos faz ver aquilo que vemos. A imagem, diz ele, vai em direção ao real, e não parte dele. O Real é o fim da imagem. A imaginação, nessa perspectiva, é o primeiro teatro da humanidade, de todos os sujeitos, que depois são bombardeados com os teatros dos sonhos, dos devaneios, das projeções. Nesse sentido,

\begin{abstract}
Afirmar a importância de favorecer o movimento de tornar-se operador fabuloso de linguagens é ressaltar que a experiência poética diz respeito ao estar em ato no mundo e não imaginar ideias sobre o mundo. Supõe negar a naturalização da imaginação como vestígio da visão ou resto perceptivo e apontar sua função projetiva do afir em linguagens. Projeção que recuperar para a racionalidade o poder produtivo das linguagens que faz o corpo aprender a lançar-se e exporse em imagens e palavras, contrariando a tendência pedagógica de ensinar a ver e ouvir por meio da contemplação e da busca de imagens no depósito mental do já visto ou sentido. Trata-se de negar uma concepção de realidade dada e fixa a ser consumida. (NAZARETH, 2012, p. 106-107)
\end{abstract}

Após o embate, príncipe e princesa finalizam o segundo ato observando o crepúsculo que se aproxima. "Que bela noite será esta!", profetiza, novamente, Nzinga. Fechando a estrutura do drama, o terceiro ato resolve o conflito, apresentando, não sem certo suspense, uma possibilidade de final feliz ao príncipe.

De fato, no terceiro ato, o discurso do príncipe muda de tom. Se antes ele ecoava dois dos principais elementos predominantes na constituição do masculino tradicional — a arrogância e o paternalismo —, no terceiro ato ele volta aniquilado pela tristeza diante do aparente fracasso. Uma leitora mais atenta possivelmente perceba nesse movimento do príncipe e seu recuo certo medo da impotência, a falência do falo, associada psicanaliticamente ao afastamento daquilo que é considerado viril, o conjunto de características que, social ou culturalmente, define o que é ser homem e o que é ser mulher. Aquele querer um amor na perspectiva do príncipe soa, assim, quase como metateatro, representação dentro da representação, daí o abismo entre o discurso do príncipe nos primeiro e terceiro atos, por exemplo. Ao sonhar e idealizar o amor no começo da ação, o príncipe representa um papel ao qual foi encarregado enquanto sujeito masculino. Uma vez que ele se vê passível de fracasso, amedronta-se, e só se acalma quando percebe, aos poucos, que sua masculinidade não deve sobrepor a feminilidade que se configura na contemporaneidade e, sim, equilibrar-se com ela sobre essa esfera que é nosso existir enquanto sociedade. É quando, enfim, o príncipe percebe que a separação entre homem e mulher não é, como ele pensava, fixa e imóvel, mas que está em constante movimento, flexibilizando-se, tornando aquele anterior muro de concreto imaginário sendo na verdade linha tênue de giz que vai aos poucos se apagando, mostrando que princesas podem tudo quanto podem os príncipes, e viceversa.

Entretanto, mesmo antes o príncipe já mostrava sinais de uma nova masculinidade, mais flexível, menos violenta e arrogante, mais empática, mais vaidosa, metrassexual até. A prática da ioga, a vida fitness, o pilates: até mesmo a alimentação dos chamados 'marombas' é lembrada no discurso do príncipe, no seu padrão de 
normalidade, e, quando colocada na boca do personagem nessas situações, o leitor/espectador percebe com facilidade quão extenso é o todo da discussão. Percebe que gênero não se limita ao sexual, mas que se estende sobre toda a esfera humana, social e política, cultural e até mesmo religiosa ou ascética.

Nossa leitura de gênero aqui é enquanto estrutura social particular, que envolve, como indica Connell e Pearse (2015, p. 47), "uma relação específica com os corpos". No senso comum, gênero indica, dicotomicamente, a expressão das diferenças naturais entre um corpo físico de homem e um corpo físico de mulher. Essas diferenças não são nuances, mas aspectos rígidos que envolvem também uma determinada forma, uma forma correta de se relacionar com os corpos.

O que está errado com a definição do senso comum não é a atenção aos corpos, nem a preocupação com a reprodução sexual, mas a tentativa de inserir a complexidade biológica e sua adaptabilidade numa dicotomia rígida, e a ideia de que os padrões culturais apenas expressariam diferenças corporais. (CONNELL; PEARSE, 2015, p. 4748)

O peso dessa dicotomia, especialmente sobre a mulher, mas que afeta a ambos, é inumano. Com o progredir do pensamento, foi necessário, sabemos, a emancipação de uma nova imagem de mulher enquanto vê-se necessária a destruição de uma imagem já estabelecida de homem. Dito de outra forma, enquanto a mulher precisa construir-se, fazer-se na sociedade enquanto indivíduo, o papel do homem é diminuir-se, fragmentarse, moldar-se à imagem dela, e não o contrário como foi desde... quando? Talvez por essa razão, o happy end: o equilíbrio é buscado e, spoiler, alcançado.

Sabemos da potência polêmica que o tema carrega para ser tratado tão brevemente, por tratar-se de questão delicada por vários motivos, para qualquer pensador e pesquisador no assunto. A sexualidade contemplada tão amplamente e, ao mesmo tempo, ser entendida socialmente como tabu parece ser o centro de uma série de questões que abrangem todas as esferas da civilização contemporânea, e pode ser, de fato, o estopim de revoluções e movimentos políticos (cf. GIDDENS, 1993, p. 11).

Além disso, o valor de obras literárias, dramáticas ou não, e estudos que tratem desses temas são excepcionalmente relevantes neste momento que é de choque, de crise, de luta e superação. E, de fato, não podemos deixar que a análise rasa da realidade nos faça regredir, visto que a sociedade está tomada de pensamentos muitas vezes forjados tendo como base aquilo que se chamou pós-verdade. Não podemos, ainda nesta mesma perspectiva de mudança e choque, esquivar-nos da realidade que se impõe: que homens e mulheres sofrem no corpo as violências desse embate, pois se é verdade que o príncipe dessa paródia surge triste e melancólico no terceiro ato, é também verdade que a maioria dos "príncipes" respondem com violência física situações como essas. Ambas perspectivas são lembradas também pelo amigo e pesquisador das masculinidades, Luiz Carlos Simon (2016, p. 5) ao dizer:

Avaliar questões como as experiências masculinas significa ingressar em território decididamente marcado por polêmicas, um espaço que tem sido ocupado em investidas ostensivas do poder público e de grupos religiosos. Além disso, os noticiários com frequência expõem atos de violência de gênero que não devem ser ignorados nem entendidos como manifestações eventuais. Nesse sentido, admitir o valor social destes estudos - que se tornam cada vez mais comuns em outras áreas do conhecimento - é passo que deve transpor qualquer reticência. 
Por fim, gostaríamos de ressaltar a poeticidade da imagem do crepúsculo, da qual já tratamos en passant e que se espelha também na linguagem e na estrutura dramática metateatral, e que no terceiro ato se revela paradoxo da resolução do conflito: como o céu é tomado de várias cores, várias possibilidades de cores em cada nascer e morrer do Sol (aproveitamento poético da regra clássica da unidade de tempo), assim também é o amor, que pode ser não uma coisa ou outra, mas as duas ao mesmo tempo, um pouco de cada uma, assim como nós, humanos, subjetivamente ambíguos e crepusculares, como cada encontro. O príncipe, que antes esperava encontrar felicidade apenas entre os seus iguais, encontra, por fim, o amor em uma personagem inesperada, que assim como o príncipe era repleta de pensamentos tradicionais, conservadores, que a privavam de viver um verdadeiro amor. Desta forma, evidencia-se na peça o caráter subjetivo, nada objetivo desse que é o nosso mais forte desejo e impulso: o desejo e a espera de um final realmente feliz.

\section{Referências}

ARISTÓFANES. Lisístrata. Trad. Millôr Fernandes. Porto Alegre: L\&PM, 2003.

BACHELARD, G. A poética do devaneio. São Paulo: Martins Fontes, 1988.

BAKHTIN, M. Estética da criação verbal. São Paulo: Martins Fontes, 2003.

BAKHTIN, M. Marxismo e filosofia da linguagem. São Paulo: Hucitec, 2006.

BARROS NETO, M. L. Psicanálise do Teatro Infantil: o papel conscientizados e terapêutico do teatro infantil. São Paulo: Traço, 1984.

BARTHES, R. A morte do autor. In. BARTHES, R. Rumor da língua. São Paulo: Martins Fontes, 2004, p. 57-64.

BERTHOLD, M. História Mundial do Teatro. São Paulo: Perspectiva, 2014.

BETTELEIM, B. A Psicanálise dos Contos de Fadas. Rio de Janeiro, Paz e Terra, 1978.

COMPAGNON, A. O trabalho da citação. Belo Horizonte: Ed. UFMG, 2007.

CONNELL, R.; PEARSE, R. Gênero: uma perspectiva global. São Paulo: NVersos, 2015.

EURÍPEDES. Medeia. Trad. Trajano Vieira. São Paulo: 34, 2010. 
FREUD, S. Escritos sobre literatura. São Paulo: Hedra, 2014.

FREUD, S. O interesse da psicanálise do ponto de vista da ciência da estética (1913). In: Totem e tabu e outros trabalhos. Rio de Janeiro: Imago, 2006.

FREUD, S. Psicanálise. In: . Um Estudo Autobiográfico, Inibições, Sintomas e Ansiedade, Análise Leiga e outros trabalhos (1925-1926). Tradução sob a direção de Jayme Salomão. Rio de Janeiro, Imago: 1996.

GIDDENS, A. A transformação da intimidade: sexualidade, amor e erotismo nas sociedades modernas. Trad. Magda Lopes. São Paulo: Unesp, 1993.

HOMERO. Odisseia. Trad. Christian Werner. São Paulo: Ubu Editora, 2018.

JENNY, L. A estratégia da forma. In: DÄLLEMBACH, L. et al. Poétique. Revista de Teoria e Análise Literárias. Intertextualidades. n. 27. Coimbra: Almedina, 1979, p. 19-45.

KRISTEVA, J. Introdução à semanálise. São Paulo: Perspectiva, 1974.

LESLIE, C.; DALAI, R. O príncipe atrasado: uma paródia teatral de contos de fadas. Londrina, PR: Madrepérola, 2018.

Nazareth, C. A. Trama: um olhar sobre o teatro infantil ontem e hoje. Rio de Janeiro: Lamparina, 2012.

PASCOLATI, S. Um mundo ao contrário, ou nem tanto. In: LESLIE, C.; DALAI, R. $O$ príncipe atrasado: uma paródia teatral de contos de fadas. Londrina, PR: Madrepérola, 2018, p. 8-12.

SAMOYAULT, T. A intertextualidade. Trad. Sandra Nitrini. São Paulo: Aderaldo e Rothschild, 2008.

SHOWALTER, E. A crítica feminista no território selvagem. In: HOLLANDA, H. B. (Org.). Tendências e Impasses: o feminismo como crítica da cultura. Rio de Janeiro: Rocco, 1994. p. 23-57. 
SILVA, E. T. O Ato de Ler: fundamentos psicológicos para uma nova pedagogia da leitura. São Paulo: Cortez, 2005.

SIMON, L. C. S. Fundamentos para pesquisas sobre masculinidades e literatura no Brasil. Revista Estação Literária. Londrina, v. 16, p. 8-28, jun. 2016. Disponível em: < http://www.uel.br/pos/letras/EL/vagao/EL16-Art1.pdf>. Acesso em: 25 jun. 2019.

SÓFOCLES. Antígona. In: A trilogia tebana. Trad. Mário da Gama Kury. Rio de Janeiro: Jorge Zahar, 1998, p. 195-254.

WOLF, N. O mito da beleza: como as imagens de beleza são usadas contra as mulheres. Tradução de Waldéa Barcellos. Rio de Janeiro: Rosa dos Tempos, 2019.

Recebido em 28 de junho de 2019

Aceito em 18 de julho de 2019 